\title{
Determinan Pemberian Makan Pada Bayi Berusia Kurang Dari Enam Bulan
}

\author{
Determinant Giving Early Food for Baby Less than Six Months
}

\author{
Rosina Kardina Kidi Hurek ${ }^{(1)}$, Odilia Esem ${ }^{(1)}$ \\ ${ }^{(1)}$ Program Studi DIII Kebidanan Universitas Citra Bangsa
}

\author{
Korespondensi Penulis: Rosina Kardina Kidi Hurek, Program Studi DIII Kebidanan \\ Universitas Citra Bangsa \\ Email: rosinakardina@gmail.com
}

\begin{abstract}
ABSTRAK
Dua tahun pertama merupakan periode terpenting dalam kehidupan anak termasuk dalam hal pemberian nutrisi. Pola asuh pemberian makan yang salah pada periode ini dapat menimbulkan masalah. Data Profil Kesehatan Kota Kupang tahun 2017 menunjukan dari 539 bayi berusia 0-6 bulan di Puskesmas Oesapa hanya 12,43\% yang mendapakan ASI Ekslusif. Penelitian ini bertujuan untuk mengetahui faktor-faktor yang berhubungan dengan pemberian makan pada bayi berusia kurang dari enam bulan yang ditinjau dari pengetahuan ibu, pendidikan ibu, dan pendapatan keluarga. Desain penelitian cross sectional dengan jumlah sampel 135 orang. Pengumpulan data menggunakan kuesioner dan analisa data terdiri dari univariat dan bivariat. Hasil penelitian menunjukan ada hubungan yang signifikan antara pengetahuan $(0,000 \alpha<0,05)$ dan pendidikan $(0,038 \alpha<0,05)$ dengan pemberian makan pada bayi kurang dari enam bulan. Diharapkan hasil penelitian ini dapat dijadikan sebagai acuan untuk meningkatkan dan membuat kebijakan juga inovasi serta perlu disosialisasikan kepada anggota keluarga untuk mendukung ibu memberikan ASI ekslusif dan pemberian MP ASI tepat 6 bulan.
\end{abstract}

Kata Kunci: Pemberian Makan Dini, Pengetahuan, Pendapatan Keluarga

\begin{abstract}
The first two years are the most important periods in a child's life including nutrition. Parenting to give the wrong food in this period can cause problems. Data Profil Kota Kupang in 2017 shows that of 539 infants showing 0-6 months at the Oesapa Health Center, only $12.43 \%$ received exclusive breastfeeding. This study purpose to study the determinant of giving early food for baby less than six months. This study use a cross-sectional design with a sample of 135 people. Data collection using a questionnaire and data analysis is chi square. Research results there was a significant relationship between knowledge $(0,000 \alpha<0,05)$ and education $(0,038 \alpha<0,05)$ giving early food for baby less than six months. It is expected that the results of this study can be made as a reference to improve and make policies also need to be socialized to family members to support mothers giving exclusive breastfeeding and giving MP ASI exactly 6 months.
\end{abstract}

Keywords: Education, Giving early food for baby, Knowledge, Family Income 


\section{PENDAHULUAN}

Salah satu sumber daya manusia yang harus dilindungi dan dijaga adalah anak. Anak merupakan generasi muda yang memiliki peran penting untuk menjaga dan meneruskan citacita bangsa. Agar peran anak ini dapat terwujud secara optimal, maka tumbuh kembang anak perlu diperhatikan. Dua tahun pertama merupakan periode terpenting dalam kehidupan anak termasuk dalam hal pemberian nutrisi. Pola asuh pemberian makan yang salah pada periode ini dapat menimbulkan masalah bagi anak yang apabila tidak diatasi secara dini dapat berlanjut hingga dewasa (Kementerian Kesehatan RI, 2018).

Pemberian MP-ASI pada bayi $<6$ bulan di Indonesia masih menjadi masalah kesehatan yang perlu mendapatkan perhatian. Hasil SDKI tahun 2012 diketahui bahwa bayi berusia 4-5 bulan yang telah mendapatkan MP ASI sebelum waktunya sebanyak $57 \%, 8 \%$ telah diberikan susu lain dan $8 \%$ diberikan air putih. Pusat Pelatihan dan Pengembangan Gizi dan Makanan Depkes melaporkan lebih dari 50\% bayi di Indonesia telah diberikan MP ASI sebelum waktunya bahkan pada bayi berusia < 1 bulan (Aldriana, 2015).

Global Strategy for Infant and Young Child Feeding, World Health Organization (WHO) dan UNICEF tahun 2018 merekomendasikan standar emas dalam pemberian makanan bagi bayi yaitu memberikan ASI dalam 30 menit segera setelah bayi lahir, memberikan ASI Ekslusif, memberikan MP ASI tepat bayi berumur 6 bulan dan meneruskan pemberian ASI sampai bayi berumur 2 tahun. Sebagai bentuk dukungan pemerintah Indonesia terhadap rekomendasi WHO, pemerintah telah mengeluarkan Peraturan Pemerintah Nomor 33 Tahun 2012 tentang Pemberian ASI Ekslusif.

Dalam pelaksanaannya masih banyak ibu yang memberikan makanan pendamping ASI (MP ASI) kepada bayi kurang dari 6 bulan. Riskesdas 2018 menunjukan 37,3\% bayi umur 0-5 bulan mendapatkan ASI ekslusif, 9,3\% mendapatkan ASI parsial dan 3,3\% mendapatkan ASI predominan. ASI predominan adalah pola pemberian ASI dimana bayi selain mendapatkan ASI juga pernah diberikan sedikit air. ASI parsial adalah pola pemberian ASI dimana bayi selain mendapatkan ASI juga diberikan makanan buatan seperti susu formula, bubur atau makanan lain sebelum bayi tepat berusia 6 bulan yang diberikan secara berkelanjutan ataupun sebelum diberikan ASI (prelakteal). Makanan prelakteal yang paling sering diberikan pada bayi baru lahir adalah susu formula $(79,8 \%)$ (Kementerian Kesehatan RI, 2018).

Pemberian MP ASI sebelum bayi berusia 6 bulan dapat meningkatkan terjadinya gastroenteritis dan resiko alergi terhadap makanan yang sangat berbahaya bagi bayi serta mengurangi produksi ASI lantaran bayi jarang menyusui. Gastroenteritis merupakan infeksi saluran pencernaan seperti muntah dan diare atau yang lebih dikenal dengan muntaber (Prasetiyono, 2014). Ini terjadi akibat belum sempurnanya sistem imun bayi sehingga jika diberikan sebelum bayi berusia 6 bulan akan rentan mengalami penyakit (Riksani, 2013). Selain itu belum ada bukti penelitian yang menunjukan bahwa pemberian mMP ASI pada bayi umur 4-5 bulan memberikan dampak yang positif. Sebaliknya hasil penelitian menunjukan bahwa pemberian MP ASI sebelum waktunya dapat meningkatkan angka kesakitan pada anak 10-20 kali dibandingkan anak yang mendapatkan MP ASI tepat waktu. Pemberian MP ASI sebelum waktunya juga meningkatkan angka kematian 7 kali dibandingkan anak yang mendapatkan MP ASI tepat waktu. Untuk kasus yang ekstrem dapat menyebabkan tersumbatnya saluran pencernaan bahkan dilakukan pembedahan (Eriza Wahyuhandani dan Trias Mahmudiono, 2017). Selain itu, pemberian MP ASI sebelum waktunya juga berpengaruh pada tingkat kecerdasan otak anak setelah dewasa dan memicu terjadinya penyakit obesitas, hipertensi dan jantung coroner (Mariani, 2016).

Keputusan ibu untuk memberikan ASI eksklusif kepada bayinya memiliki pengaruh yang sangat besar. Salah satu faktor yang mempengaruhi keputusan ibu adalah pengetahuan ibu. Ibu yang kurang mengetahui manfaat ASI Ekslusif sering beranggapan bahwa bayi yang kecil dan kurus perlu diberikan makanan tambahan selain ASI untuk mencukupi kebutuhan gizi bayinya selama 6 bulan. Lolli Nababan dan Sari Widianingsih (2018) dalam penelitiannya mengatakan bahwa ada hubungan antara factor pendidikan ibu dan pengetahuan ibu dengan pemberian MP-ASI dini (Nababan, Lolli, 2018).

Pengetahuan ibu tentang pemberian MP ASI erat hubungannya dengan informasi yang diperoleh ibu baik dari lingkungannya maupun 
media massa. Ibu mengatakan seringkali memberikan MP ASI sebelum bayi tepat berusia 6 bulan karena adanya kebiasaan turun temurun dari orang tua yang telah memberikan makanan tambahan seperti bubur nasi dan bubur pisang pada bayi usia 3 bulan. Tidak hanya itu, ibu juga mengatakan faktor utama memberikan MP ASI karena tertarik dengan iklan susu formula maupun MP ASI yang sekarang banyak sekali beredar di televisi maupun di media sosial yang diperkenalkan produsen sehingga ibu tertarik untuk memberikan susu formula bayinya (Ginting, D, Sekawarna, N \& Sukandar, 2013).

Faktor lain yang mempengaruhi pemberian MP ASI yang terlalu dini adalah pendidikan ibu. Ibu yang memiliki tingkat pendidikan lebih tinggi diharapkan memiliki pengetahuan yang lebih baik karena lebih mudah menyerap dan menyaring informasi yang diperoleh baik dari lingkungan kehidupan sehari-hari maupun media massa tentang pemberian MP-ASI pada bayi dibandingkan ibu dengan pendidikan rendah Semakin tinggi tingkat pendidikan seseorang maka akan semakin mudah menyerap dan menyaring informasi yang diperoleh (Aldriana, 2015).

Selain itu, pendapatan keluarga juga berpengaruh dalam pemberian MP ASI dini. Hal ini dikarenakan keluarga dengan perekonomian yang lebih baik akan memiliki kemampuan untuk membeli MP ASI lebih mudah dibandingkan dengan keluarga dengan perekonomian rendah. Hasil penelitian menunjukan bahwa keluarga dengan perekonomian menengah ke atas lebih cepat memberikan MP ASI. Pendapatan keluarga berhubungan positif secara signifikan dengan pemberian susu formula dan makanan pabrik (Kumalasari, 2015).

Data Profil Kesehatan Kota Kupang tahun 2017 menunjukan bahwa dari 539 bayi berusia $0-6$ bulan yang berada di wilayah kerja Puskesmas Oesapa hanya 12,43 \% yang mendapakan ASI Ekslusif. Keadaan ini tentunya sangat memprihatinkan mengingat peran ASI yang sangat besar bagi tumbuh kembang bayi (Dinas Kesehatan Kota Kupang, 2017).

Tujuan dilakukannya penelitian ini adalah mengetahui lebih lanjut tentang hubungan antara pengetahuan, pendidikan dan pendapatan keluarga dengan pemberian makan pada bayi $<6$ bulan.

\section{SUBYEK DAN METODE}

Penelitian ini bersifat analitik dengan pendekatan kuantitatif. Desain penelitian yang digunakan adalah cross sectional (potong lintang) yaitu subjek hanya diobservasi sekali saja dan pengukuran dilakukan terhadap variabel dependen dan independen secara bersamaan pada suatu saat (Notoatmodjo, 2012a). Variable dependen dalam penelitian ini yaitu pemberian makan pada bayi $<6$ bulan sedangkan variabel independen terdiri dari pengetahuan, pendidikan dan pendapatan keluarga. Adapun definisi operasional dari setiap variabel yaitu

a) Pemberian makan pada bayi $<6$ bulan: Perilaku memberikan makanan atau minuman yang mengandung zat gizi selain ASI pada bayi atau anak berusia $<6$ bulan.

b) Pengetahuan ibu: Kemampuan responden menjawab pertanyaan dengan baik dan benar mengenai pengetahuan ibu tentang pemberian makanan pada bayi dengan indikator pengertian MP ASI dan ASI Ekslusif, manfaat MP ASI, Waktu pemberian MP ASI, bentuk MP ASI, resiko memberikan MP ASI pada bayi $<6$ bulan.

c) Pendidikan ibu: Proses belajar formal yang telah ditamatkan responden (SD, SMP, SMA, Perguruan Tinggi).

d) Pendapatan Keluarga: Upah/penghasilan yang diterima baik dari lingkungan usaha/pekerjaannya setiap bulan dengan indicator standar UMR (upah minimum regional Rp. 1.500.000,00)

Penelitian ini dilakukan di wilayah kerja Puskesmas Oesapa Kota Kupang sejak tanggal 1 februari sampai dengan 29 februari 2020. Populasi dalam penelitian ini adalah seluruh ibu yang memiliki bayi berusia 0 sampai 6 bulan di Puskesmas Oesapa yang berjumlah 539 orang dengan jumlah sampel 135 orang. Untuk menentukan besarnya sampel apabila subjek kurang dari 100, lebih baik diambil semua sehingga penelitiannya penelitian populasi, namun jika subjeknya lebih besar dari 100 maka sampel dapat diambil antara $10-15 \%$ atau 20-25\%. Dalam penelitian ini digunakan sampel 25\% (Arikunto, 2015). Teknik pengambilan sampel menggunakan purposive sampling dengan kriteria inklusi yaitu ibu yang memiliki bayi berusia 0 sampai 6 bulan yang sudah ataupun belum memberikan MP ASI pada bayinya di Puskesmas Oesapa Kota Kupang. Instrumen yang digunakan adalah kuesioner. Teknik analisa data menggunakan 
uji chi square dengan aplikasi spss versi 20. Penyajian data secara naratif dan tabular.

\section{HASIL}

Berdasarkan Tabel 1 di bawah ini diketahui bahwa dari 135 responden sebanyak 70 responden $(51,9 \%)$ memberikan makan pada bayi kurang dari 6 bulan dan 65 responden $(48,1 \%)$ memberikan makan pada bayi di usia $>6$ bulan. Dari 135 responden sebanyak 79 responden $(58,5 \%)$ memiliki pengetahuan kurang tentang pemberian makanan pendamping ASI dan 56 responden $(41,5 \%)$ memiliki pengetahuan baik tentang pemberian makan pada bayi 6 bulan. Dari 135 responden terdapat 63 responden $(48,7)$ yang termasuk dalam kategori tingkat pendidikan rendah (SDSMP) dan sisanya 72 responden $(53,3)$ termasuk dalam kategori tingkat pendidikan tinggi (SMA-PT). Dan dari 135 responden terdapat 68 responden $(50,4 \%)$ memiliki pendapatan per bulan < UMR RP.1.500.000,00 dan sisanya 67 responden memiliki pendapatan per bulan > UMR Rp. 1.500.000,00. Tabel 2 menunjukan bahwa pengetahuan memiliki hubungan yang significant dengan pemberian makanan pada bayi $<6$ bulan dengan $p$ value
$0,000<0,05$ dan nilai OR 4,066 $(1,962-8,424)$ yang artinya ibu dengan kategori tingkat pengetahuan kurang memiliki peluang 4,066 kali lebih besar memberikan makan pada bayi berusia $<6$ bulan dibandingkan dengan ibu yang memiliki tingkat pengetahuan baik.

Selanjutnya, variabel pendidikan juga memiliki hubungan yang signifikan dengan pemberian makanan pada bayi $<6$ bulan dengan $p$ value $0,038>0,05$ dan nilai OR 2,149 $(1,078-4,285)$ yang artinya ibu dengan kategori tingkat pendidikan rendah memiliki peluang 2,149 kali lebih besar memberikan makan pada bayi berusia $<6$ bulan dibandingkan dengan ibu yang memiliki tingkat pendidikan tinggi. Terakhir, variabel pendapatan keluarga tidak memiliki hubungan yang significant dengan pemberian makan pada bayi $<6$ bulan dengan $p$ value $0,086>0,05$. Hasil analisis lebih lanjut diketahui nilai OR $0,533(0,269-1,056)$ yang artinya keluarga dengan pendapatan < UMR Rp. 1.500 .000 memiliki peluang 0,533 kali lebih besar memberikan makan pada bayi berusia < 6 bulan dibandingkan dengan keluarga dengan pendapatan > UMR Rp. 1.500.000.

Tabel 1. Rekapitulasi Analisis Univariat

\begin{tabular}{lcc}
\hline \multicolumn{1}{c}{ Variabel (n=135) } & Frekuensi & Persentase (\%) \\
\hline Pemberian Makan Pada Bayi & & \\
Pemberian Makan < 6 bulan & 70 & 51,9 \\
Pemberian Makan 6 bulan & 65 & 48,1 \\
\hline Pengetahuan Ibu & 79 & 58,5 \\
Kurang & 56 & 41,5 \\
Baik & & \\
\hline Pendidikan Ibu & 63 & 46,7 \\
Rendah (SD-SMP) & 72 & 53,3 \\
Tinggi (SMA-PT) & & \\
\hline Pendapatan Keluarga & 68 & 50,4 \\
< UMR Rp. 1.500.000 & 67 & 49,6 \\
Z UMR Rp. 1.500.000 & &
\end{tabular}


Tabel 2. Rekapitulasi Analisis Bivariat

\begin{tabular}{|c|c|c|c|c|c|c|c|c|}
\hline \multirow[t]{3}{*}{ Variabel } & \multicolumn{4}{|c|}{ Pemberian Makan Pada Bayi } & \multirow{2}{*}{\multicolumn{2}{|c|}{ Total }} & \multirow[t]{3}{*}{ P Value } & \multirow[t]{3}{*}{ OR (CI 95\%) } \\
\hline & \multicolumn{2}{|c|}{$<6$ bln } & \multicolumn{2}{|c|}{6 bulan } & & & & \\
\hline & $\mathbf{n}$ & $\%$ & $\mathbf{n}$ & $\%$ & $\mathbf{N}$ & $\%$ & & \\
\hline \multicolumn{9}{|c|}{ Pengetahuan ibu } \\
\hline Kurang & 52 & 65,8 & 27 & 34,2 & 79 & 100 & $\mathbf{0 , 0 0 0}$ & $4,066(1,962-8,424)$ \\
\hline Baik & 18 & 32,1 & 38 & 67,9 & 56 & 100 & & \\
\hline Total & 70 & 51,9 & 65 & 48,1 & 135 & 100 & & \\
\hline \multicolumn{9}{|c|}{ Pendidikan ibu } \\
\hline Rendah & 39 & 61,9 & 24 & 38,1 & 63 & 100 & $\mathbf{0 , 0 3 8}$ & $2,149(1,078-4,285)$ \\
\hline Tinggi & 31 & 43,1 & 41 & 56,9 & 72 & 100 & & \\
\hline Total & 70 & 51,9 & 65 & 48,1 & 135 & 100 & & \\
\hline \multicolumn{9}{|c|}{ Pendapatan Keluarga } \\
\hline $\begin{array}{l}<\text { UMR } \\
\text { Rp.1.500.000 }\end{array}$ & 30 & 44,1 & 38 & 55,9 & 68 & 100 & 0,086 & $0,533(0,269-1,056)$ \\
\hline $\begin{array}{l}>\text { UMR } \\
\text { Rp. } 1.500 .000\end{array}$ & 40 & 59,7 & 27 & 40,3 & 67 & 100 & & \\
\hline Total & 70 & 51,9 & 65 & 48,1 & 135 & 100 & & \\
\hline
\end{tabular}

\section{DISKUSI}

\section{Hubungan antara Pengetahuan dengan Pemberian Makan Pada Bayi < 6 Bulan}

Hasil penelitian menunjukan bahwa sebagian besar ibu $(58,5 \%)$ memiliki pengetahuan kurang tentang pemberian makan pada bayi kurang dari 6 bulan. Hasil analisis bivariat menunjukan ada hubungan yang signifikan antara pengetahuan dengan pemberian makan pada bayi berusia kurang dari enam bulan dengan nilai $p$ value $(0,000)$. Ibu yang berpengetahuan kurang memiliki kecendrungan 4,066 kali lebih besar untuk memberikan makanan tambahan pada bayi $<6$ bulan dibandingkan dengan ibu yang berpengetahuan baik.

Hasil ini sama dengan penelitian Nana aldriana dimana ada hubungan antara pengetahuan dengan MP ASI dini ( $p$ value $0,048<0,05)$ (Aldriana, 2015). Namun, hasil penelitian ini bertentangan dengan penelitian Mariani (2016) dimana tidak terdapat hubungan yang signifikan antara pengetahuan dengan pemberian MP ASI dini ( $p$ value 1,000 >0,05) (Mariani, 2016). Lawrence Green mengatakan bahwa banyak faktor yang erat kaitannya dengan perilaku seseorang dan pengetahuan adalah salah satunya. Ibu dengan pengetahuan yang baik tidak selalu menghasilkan perilaku yang baik. Ketika responden telah memiliki pengetahuan yang baik namun adanya adat kebiasaan di masyarakat untuk memberikan MP ASI sebelum bayi tepat 6 bulan dengan asumsi ASI saja tidak cukup memenuhi kebutuhan gizi bayi dan memberikan ras kenyang kepada bayi, maka ibu juga kemungkinan akan memberikan makanan tambahan untuk bayinya.

Pengetahuan dapat diartikan sebagai hasil dari usaha penginderaan terhadap objek tertentu dan indera manusia yang paling sering digunakan untuk memperoleh pengetahuan adalah mata dan telinga (Notoatmodjo, 2012a). Makanan yang paling baik untuk bayi $<6$ bulan adalah ASI. ASI memiliki zat gizi yang paling tepat dan sesuai dengan kebutuhan bayi sehingga dapat mengurangi kejadian infeksi maupun gangguan pencernaan dan alergi pada bayi. Selain itu, ASI juga dapat meningkatkan daya tahan tubuh bayi dan membantu terjalinnya hubungan kasih sayang ibu dan bayi. Bayi baru diberikan MP ASI ketika tepat berusia 6 bulan (Paramashanti, 2019).

Nutrion \& Health Surveillance System (NSS) pada tahun 2010 melaporkan bahwa pemberian MP ASI di pedesaan paling tinggi diberikan pada bayi berusia 45 bulan $(4 \%-25 \%)$ dan di usia 5-6 bulan proporsinya menurun menjadi hanya sebesar 1\%-13\%. Hal ini terjadi karena ibu memiliki keyakinan bahwa dengan bertambahnya usia bayi maka kebutuhan gizi bayi juga meningkat sehingga ASI saja tidak cukup. Secara biologis kejadian kurangnya produksi ASI pada ibu hanya seketar 2-5\%. Selain itu, ibu memiliki ketakutan bahwa bayi yang hanya diberikan ASI akan tumbuh dan berkembang menjadi 
anak yang manja serta ibu yang bekerja terpaksa harus memberikan makanan tambahan berupa susu formula (Nababan, Lolli, 2018).

2. Hubungan antara Pendidikan dengan Pemberian Makan Pada Bayi < 6 Bulan

Hasil penelitian menunjukan bahwa dari 135 ibu sebanyak 72 responden $(53,3$ $\%)$ memiliki tingkat pendidikan tinggi (SMA-PT). Hasil analisis lebih lanjut menunjukan bahwa ada pendidikan memiliki hubungan yang significant dengan pemberian makan pada bayi $<6$ bulan. Ibu dengan tingkat pendidikan rendah memiliki kecenderungan 2,149 kali lebih besar memberikan makanan tambahan pada bayi $<6$ bulan di bandingkan ibu yang memiliki tingkat pendidikan tinggi.

Hal ini sejalan dengan penelitian yang dilakukan oleh Nababan (2018) yang menunjukan bahwa ada hubungan yang signifikan antara pendidikan dengan pemberian MP ASI dini ( $p$ value 0,003). Penelitian ini sama dengan penelitian Afriyani (2016) dimana diketahui bahwa pendidikan ibu memiliki hubungan dengan pemberian MP-ASI pada bayi usia 0- 6 bulan di BPM Nurtila Palembang tahun 2016 (p-value $0,034<\alpha 0,05$ ) dan nilai $\mathrm{OR}=8,000$, yang artinya ibu berpendidikan rendah memiliki peluang 8,000 kali lebih besar memberikan MP-ASI pada bayi usia 0 6 bulan dibandingkan dengan ibu yang berpendidikan tinggi (Rahmalia Afriyani, Shintya Halisa, 2016).

Kegagalan dalam pemberian ASI Eksklusif disebabkan oleh pemberian MPASI secara dini. Menurut Baharudin (2014) dalam Afriyani (2016) tingkat pendidikan ibu yang rendah mengakibatkan ibu lebih sering memberikan bayinya susu botol daripada disusui langsung oleh ibunya, bahkan pada kasus yang ekstrem bayi yang baru berusia 1 bulan sudah diberi pisang atau nasi lembut sebagai tambahan ASI. Hal ini terjadi karena sebagian masyarakat masih beranggapan bahwa dalam pemberian MP-ASI pada anak dikarenakan anak rewel atau menangis yang dianggap sebagai tanda bahwa bayi lapar. Selain itu, pengaruh orang tua yang zaman dahulu untuk memberikan makanan pendamping pada usia dini agar tercukupi semua kebutuhan anak tersebut (Utami, 2014).
Kebiasaan daerah setempat mengenai pemberian makanan atau minuman prelakteal dan MP-ASI dini seperti air zamzam, bubur pisang, belum mendukung terlaksananya pemberian ASI eksklusif. Kebiasaan atau tradisi ini mungkin merupakan faktor yang mempengaruhi dukungan keluraga baik ibu, mertua dan suami untuk memberikan MP-ASI dini dan makanan Prelakteal (Yeni \& Minsarnawati, 2012). Selanjutnya, kebiasaan atau tradisi memberikan makanan prelakteal atau MPASI dini dapat mengakibatkan terhambatnya proses menyusui ibu dan kegagalan ASI Ekslusif (Sutayani, 2012).

Oleh karena itu, pendidikan yang dijalani seseorang erat kaitannya dengan peningkatan kemampuan berfikir dimana seseorang yang berpendidikan lebih tinggi umumnya akan lebih terbuka dalam menyerap, menerima dan menyaring informasi atau hal baru dan mengambil keputusan yang lebih rasional di bandingkan dengan individu yang berpendidikan lebih rendah (Notoatmodjo, 2012b). Hal inilah penting bagi tenaga kesehatan untuk memberikan konseling informasi dan edukasi tentang pemberian MP ASI tidak hanya kepada ibu tetapi juga keluarga sehingga diharapkan dengan adanya informasi dari tenaga kesehatan dan dukungan dari keluarga maka ibu secara psikologis akan semangat dalam memberikan ASI Eksklusif dan menunda pemberian makan sampai bayi genap berusia 6 bulan.

3. Hubungan antara Pendapatan Keluarga dengan Pemberian Makan Pada Bayi < 6 Bulan

Hasil penelitian menunjukan bahwa dari 135 ibu terdapat $68 \quad(50,4 \%)$ ibu memiliki pendapatan keluarga per bulan < UMR Rp.1.500.000. Hasil penelitian lebih lanjut menunjukan bahwa pendapatan keluarga tidak memiliki hubungan dengan pemberian makan pada bayi berusia $<6$ bulan (nilai $p$ value 0,086 ) namun hasil uji OR menunjukan keluarga dengan pendapatan > UMR Rp. 1.500.000 memiliki kecendrungan 2 kali lebih besar memberikan makanan tambahan pada bayi kurang dari enam bulan dibandingkan keluarga dengan pendapatan keluarga < UMR Rp. 1.500.000. 
Hasil penelitian ini bertolak belakang dengan penelitian afriyani (2016) dimana hasil uji chi square menunjukan pendapatan keluarga memiliki hubungan dengan pemberian MP-ASI pada bayi usia 0 sampai 6 bulan di BPM Nurtila Palembang tahun 2016 dan nilai $\mathrm{OR}=13,750$ yang artinya $\mathrm{ibu}$ dengan pendapatan keluarga yang tinggi memiliki peluang 13,750 kali lebih besar memberikan MP-ASI pada bayi usia 0-6 bulan dibandingkan dengan ibu yang pendapatan keluarganya rendah (Rahmalia Afriyani, Shintya Halisa, 2016). Hal ini sama dengan penelitian Wiwi di Puskesmas Sukaraja Kabupaten Bogor tahun 2012 dimana hasil penelitian menunjukan ibu dengan pendapatan keluarga > UMR sebanyak $68,2 \%$ yang berpengetahuan baik tentang pemberian makanan tambahan pada bayi 0 sampai 6 bulan dan ibu yang berpendapatan keluarga > UMR sebanyak $42,7 \%$ yang berpengetahuan baik tentang pemberian makanan tambahan pada bayi 0 sampai 6 bulan, serta terdapat hubungan antara pendapatan keluarga dengan pemberian makanan tambahan pada bayi 0 sampai 6 bulan.

Perekonomian keluarga yang baik memberikan kesempatan pada ibu untuk lebih mudah membeli dan memberikan MP ASI pada bayi < 6 bulan. Hal ini akan sulit jika ibu memiliki pendapatan keluarga yang rendah (perekonomian yang buruk). Bukti penelitian menunjukan tingkat pendapatan keluarga memiliki hubungan dengan pemberian makanan pendamping ASI pada bayi < 6 bulan. Pada keluarga dengan golongan ekonomi menengah ke atas memiliki kecenderungan lebih cepat memberikan MP ASI pada bayi sbelum bayi tepat berusia 6 bulan. Penghasilan keluarga yang lebih tinggi memiliki hubungan positif secara signifikan dengan pemberian susu formula dan makanan buatan pabrik sebelum bayi berusia 6 bulan (Kumalasari, 2015).

Lawrence Green mengatakan bahwa perilaku dipengaruhi oleh tiga faktor yaitu faktor presdisposisi, faktor pendukung dan pendorong. Faktor presdiposisi terdiri dari pengetahuan individu, sikap, kepercayaan, tradisi, norma sosial, keadaan ekonomi dan unsur-unsur lain yang terdapat dalam diri individu. Faktor pendukung ialah tersedianya akses dan pelayanan kesehatan sedangkan faktor pendorong terdiri dari sikap dan perilaku petugas kesehatan (Nurmala, Ira, 2018).

Peneliti menyimpulkan pendapatan keluarga tidak menjamin ibu akan memberikan MP ASI tepat waktu kepada bayi karena banyak faktor yang mempengaruhi keputusan ibu untuk memberikan ASI ekslusif dan menunda MP ASI sampai bayi genap berusia 6 bulan. Petugas kesehatan harus terus memberikan informasi tidak hanya kepada ibu yang memiliki balita tetapi juga kepada ibu hamil sebagai persiapan untuk menyusui nanti. Selain itu, perlu ada kerja sama lintas sektoral untuk terus memberdayakan masyarakat dalam pemberian informasi kepada keluarga sehingga dengan adanya dukungan keluarga maka ibu akan lebih menyakini untuk bisa memberikan MP ASI tepat waktu.

\section{KESIMPULAN}

Berdasarkan hasil penelitian ini dapat disimpulkan bahwa dari 3 variabel yang diteliti terdapat dua variable yang memiliki hubungan signifikan dengan pemberian makan pada bayi < 6 bulan di Puskesmas Oesapa Kota Kupang tahun 2019 yaitu variable pengetahuan (nilai $P$ value 0,000 , OR : 4,066 (1,962-8,424)) dan variable pendidikan (nilai $P$ value 0,038 , OR : $2,149 \quad(1,078-4,285))$, sedang variable pendapatan keluarga tidak memiliki hubungan yang signifikan dengan pemberian makan pada bayi $<6$ bulan (nilai $P$ value $0,086>\alpha 0,05$, OR : $0,533(0,269-1,056))$. Diharapkan hasil penelitian ini dapat dijadikan sebagai acuan dalam meningkatkan dan membuat kebijakan serta inovasi-inovasi yang dapat mendukung ibu untuk memberikan ASI ekslusif dan MP ASI tepat waktu kepada bayinya. Selain itu, informasi tentang pentingnya ASI ekslusif perlu untuk diinformasikan tidak hanya kepada ibu tetapi juga anggota keluarga lainnya sehingga dapat terbentuk dukungan keluarga untuk mendukung ibu memberikan ASI ekslusif sehingga pemberian MP ASI dapat diberikan tepat 6 bulan.

\section{DAFTAR PUSTAKA}

Aldriana, N. (2015). Faktor-Faktor Yang Berhubungan Dengan Pemberian Mp-Asi Dini Di Desa 2 Dayo Wilayah Kerja Puskesmas Tandun Ii Kabupaten Rokan Hulu Tahun 2013. Jurnal Maternity and 
Neonatal, Volume $2 \mathrm{~N}$.

Arikunto. (2015). Prosedur Penelitian Suatu Pendekatan Praktek. Jakarta: Rineka Aksara.

Dinas Kesehatan Kota Kupang. (2017). Profil Kesehatan Kota Kupang.

Eriza Wahyuhandani dan Trias Mahmudiono. (2017). Hubungan Pengetahuan Gizi dan Pekerjaan Ibu Terhadap Pemberian MPASI Dini di Puskesmas Telaga Biru Kota Pontianak Tahun 2014. Amerta Nutricion, Vol 11 No https://doi.org/10.2473/amnt.v1i4.2017.3 00-307

Ginting, D, Sekawarna, N \& Sukandar, H. (2013). Pengaruh karakteristik, faktor internal dan eksternal ibu terhadap pemberian MP-ASI dini pada bayi usia < 6 bulan di wilayah kerja Puskesmas Barus Jahe Kabupaten Karo Provinsi Sumatera Utara. FK Universitas Padjajaran.

Kementerian Kesehatan RI. (2018). Infodatin Menyusui Sebagai Dasar Kehidupan.

Kumalasari, S. Y. (2015). Faktor-Faktor Yang Berhubungan Dengan Pemberian Makanan Pendamping Asi Dini. JOM Vol 2 No 1.

Mariani, N. N. (2016). Faktor-Faktor Yang Berhubungan Dengan Pemberian Mp-Asi Dini Di Wilayah Kerja Uptd Puskesmas Sindanglaut Kecamatan Lemahabang Kabupaten Cirebon. Jurnal Kesehatan, Volume VII.

Nababan, Lolli, S. W. (2018). Pemberian MP ASI Dini ditinjau dari pendidikan dan pengetahuan ibu. Jurnal Keperawatan Dan Kebidanan Aisyiyah, Vol 14, No.

Notoatmodjo. (2012a). Metodologi Penelitian Kesehatan. Jakarta: Rineka Cipta.

Notoatmodjo. (2012b). Promosi Kesehatan dan Perilaku Kesehatan. Jakarta: Rineka Cipta.

Nurmala, Ira, et al. (2018). Promosi Kesehatan. Surabaya: Airlangga University Press.

Paramashanti, B. A. (2019). Gizi bagi ibu dan Anak. Yogyakarta: Pustaka Baru.
Prasetiyono. Makanan Tambahan Penganti ASI. , (2014).

Rahmalia Afriyani, Shintya Halisa, H. R. (2016). Faktor - Faktor yang Berhubungan dengan Pemberian MP-ASI pada Bayi Usia 0-6 Bulan di BPm Nurtila Palembang. Jurnal Kesehatan Poltekes Kemenkes Tanjung Karang, Volume $7 \mathrm{~N}$.

Riksani, R. (2013). Variasi olahan makanan pendamping ASI. Jakarta: Dunia Kreasi.

Sutayani, D. P. (2012). Hubungan Pemberian Makanan Prelakteal dengan Proses Menyusui di Wilayah Kerja puskesmas Rowotengah Kecamatan Sumber Baru, Jember. Skripsi Universitas Jember.

Utami, H. (2014). Budaya pemberian makanan pendamping ASI dini pada ibu yang mempunyai anak 7-24 bulan di Desa Argodadi Sedayu Bantul Yogyakarta. Jurnal Kesehatan STIKES Aisyiyah Yogyakarta.

Yeni \& Minsarnawati. (2012). Perilaku yang Menghambat Pemberian ASI Ekslusif pada Ibu di Wilayah Kerja Puskesmas Cibeber. Jurnal Kesehatan Reproduksi, $3(3)$. 